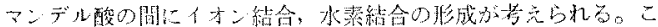

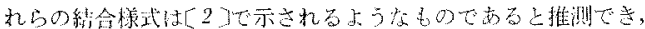

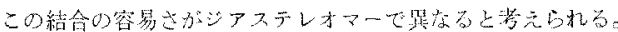

$$
\langle\overline{\mathrm{O}}\rangle-\mathrm{CH}_{2}-\mathrm{CH}\left\langle\stackrel{\stackrel{\oplus}{\mathrm{N}} \mathrm{H}_{3} \mathrm{O} \mathrm{OC}}{\mathrm{C}=\mathrm{O} \ldots \mathrm{HO}}\right\rangle \mathrm{CH}-\langle\mathrm{O}\rangle
$$

優先的に生成吉当 L-Phe-L-マンデル酸複合休のマンデル酸の -OH の服取は $\mathrm{D}-$ マンデル酸複合体の $-\mathrm{OH}$ の䏜收 $\left(3350 \mathrm{~cm}^{-1}\right)$ 上り低被数側 $\left(3250 \mathrm{~cm}^{-1}\right)$ にあり，九のキレーションが䟻いこと 䘮している。マンデル酸のカルボキシル䓠の财收は Dーマンデ ル酸で梳化はないが，レーマンデル酸の場合は低波数側(1680 $\mathrm{cm}^{-1}$ )に移動し，イオン結合の強いこと宗唆している。この文 うなイオン絬合，水素結合が強いほど沈段しやすいことは理解で きる。ジステレオマーの結合の相違は二次元的に考えては説明 马るのが困難であり，三次元的な複合体の㯜造家若える必要があ bo

\section{4 フェニルアラニンとマンデル酸の不整相互作用機浾}

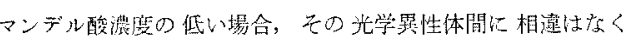

L-Phe の溶解度を直線的に高的当こと名ら，宋す1】の形成が若 えられる。マンデル酸淟度が高くなるを沈殿が生成することか ら，〔1〕が非成されたのら他のマンデル酸分子が Phe の逆の面 八接近し，この上き败存のマンデル酸分子と逆方向を向いて接近 し, Phe とイオン結合, 水䋕結合, 芳䅛環の間に䟢水結合を形成 子る。この場合, 立体棰造の違いで L-Phe-L-マンデル酸の方が 相互作用子るのに有利姑ると考兑られる。不整相互作用の模式 沧家図6に示した。

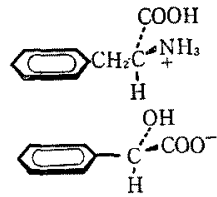

L-Phe $-\mathrm{D}-マ ン テ ゙ ル$ 酸

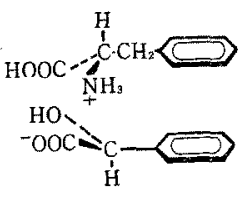

L-Phe-L-マンデル酸
図 6 Phe-マソデル酸の不整相互作用

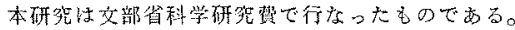

四塩化炭素-水酸化アルカリ法を用いたクロルフェノール類のカルボキシル化反応による

\title{
若干のクロルヒドロキシ安息香酸類およびその誘導体の合成
}

(昭和 46 籍 7 月 23 日受理)

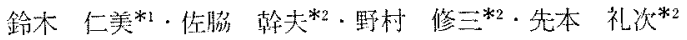

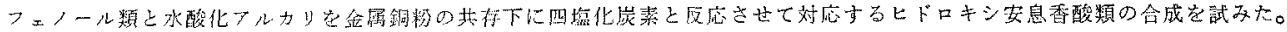

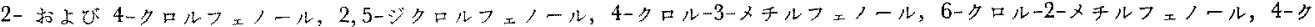

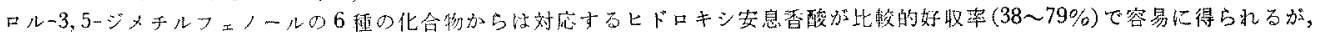

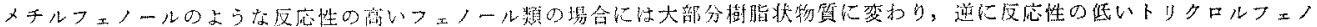

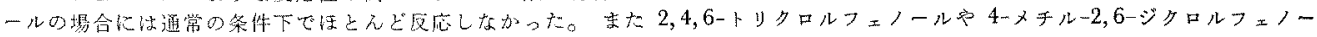

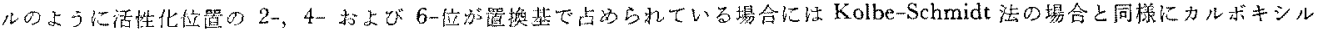

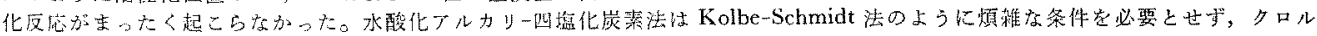

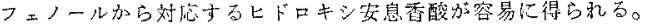

\section{1 緒言}

ヒドロキシ多息香酸誘導体の殺菌，殺ダニ性の研究に闑連して 若干の置換クロルヒドロキシ安息香酸が必要をなったので，对応 するクロルつェイール頪の直接力ルボキシル化反沁によってこれ

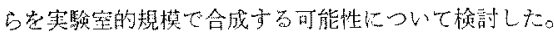

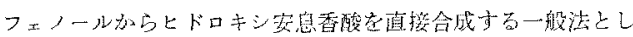

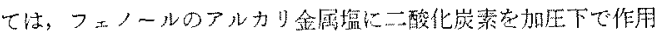

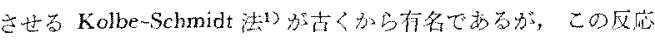

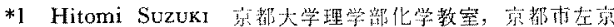
区北白川媳分町

*2 Mikio Sawakr, Syûzô Nomura, Reiji Sakimoto 日本

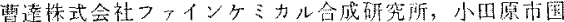
府㴋

1) H. Kolbe, Ann., 113, 125(1860); R. Schmidt, J. Prakt. Chem., [2], 31, 397(1885); A. S. Lindsey, H Jeskey, Chem. Revs., 57, 583(1957)
は高温加压の条件を必要と寸るほか，電子吸引性置換基索もつつ

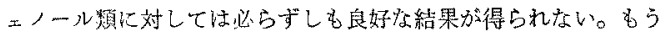
一つの直接的合成法としてアルカリ共存下に利りるフェールと 四壦化炭秦の反応がある゙。この反応梳高温加生の反応条件を必 要とするほか，副反応がいるじるしいため実際の合成にはほとえ ど用いられていないが，金属銅粉索触媒にすると常压下で反応を 行なえることが指摘されているのでタ，フェノールとその若阫の 核造㨦誘導体について Kolbe-Schmidt 法との比較を行なった。 その結果，反応性の高いフェノール類の場合には多量の綟合物が 生成するので使用に耐党标いが，八ロフェノールのようにやや反 栍が抑えられたフェノール類の場合にはカルボキシル化反応か

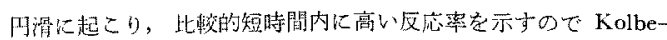

2) K. L. Reimer, F. Tiemann, Ber., 9, 1285(1876); G. Hasse, ibid., 10, 2185(1877).

3) J. Zeltner, M. Landau, Ger. P., 258, 887 (1913); Chem. Zentr., 84, 1, 1641 (1913) 


\begin{tabular}{|c|c|c|c|}
\hline クロルフェノール & ヒトロキシ安息霄酸 & ff $\left({ }^{\circ} \mathrm{C}\right) 0$ & \\
\hline 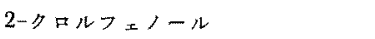 & 3ークロルー4ーヒドロキシ安息香酸 & $\left.161 \sim 165(164 \sim 165)^{4}\right)$ & 79 \\
\hline 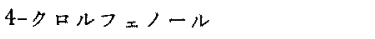 & 5ークロルー2ーヒドゥキシ葸息香酸 & $\left.172 \sim 172.4(173 \sim 174)^{5}\right)$ & 64 \\
\hline 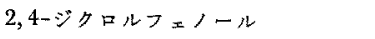 & 3,5-ジクロルー2ーヒドロキシ卖息香酸 & $\left.223(223)^{6}\right)$ & 11 \\
\hline 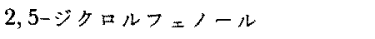 & 2,5ージタロルー4ーヒドロキシ安息香酸 & $219 \sim 220 * 5(258) \gg$ & 74 \\
\hline 2,6 -ジクロルフェノール & 3,5-ジクロルー4ーヒドロキシ安息香酸 & $245 \sim 250(255 \sim 256)^{8)}$ & $<5$ \\
\hline 6-タロル-2-メテルフェイール & 5ータロルー4ーヒドロキシー3ーメチル安息香酸 & $\left.240 \sim 242^{a}\right\rangle$ & 70 \\
\hline 4-クロルー3-メチルフ =1ール & 5ータロル-2-ヒドロキシー4-メチル安息香酸 & $\left.185 \sim 197^{b}\right)(210 \sim 212)^{8)}$ & 38 \\
\hline 4-クロル-3,5-ジメチルフェノール & 3ークロルー6ー七ドロキシ-2,4-ジメチル安息香酸 & $196.5 \sim 198(193)^{10)}$ & 54 \\
\hline $2,4,5$-トリクロルフェノール & 3,5,6ートリタロルー2ーヒドロキシ安息番酸 & $208 \sim 210(206 \sim 207)^{11)}$ & $\sim 0$ \\
\hline
\end{tabular}

䒠測值 C $51.39 \% ，$ H $4.01 \%$

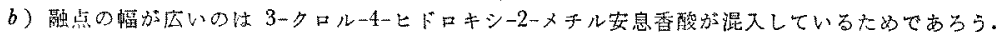

c) カッコ内の融点隹文献値を示守.

Schmidt 法の相補的方法として使用できることがわかった。4-位 に置換基をむたないハロフェノール類からハロゲン置換の 4 - ヒ ドロキシ安息香酸類合成したい場合には，これらのフェノール

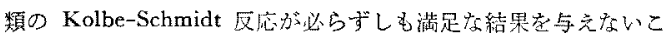
とが多いので，合成面からみて意義が故ると考充られる。とく に, Kolbe-Schmidt 法分必要とする特殊な加在装䈯や高温の条

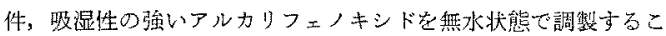
となどという颛雑な条件を必要としない点で，水酸化アルカりー

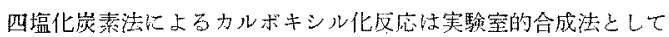
便租なこ上がわかっでので報告する。

\section{2 結果亡考察}

アルカリ其存下汇和けるフェノール上四㦈化炭素との反心につ いては Reimer と Tiemannら”肪古く 1876 年に封管反底に上 ってカルボン酸が生成することを報告し，Zeltnerらによって銅 粉触媒を用いると常圧でも反忘が進行吉ることが指摘されて以来

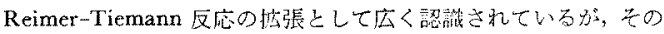
区底の具体的性格についてはほをえど知られていない。るこで ロルフェノール類との反応老行ならにさき立ってつェノールを对 照に選び，1/10 モルスケールで反条件の检徱悹行なった。触

*3 Kolbe-Schmidt 法によるハロフェノールのカルボキシ ル化では2ーヒドロキシ安息香酸誘道体のみが生成与る。 これをサリチル酸の異性化の場合のように加熱操作仁上

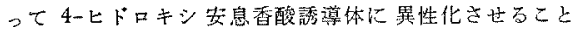
はできい。

L. Varnholt, J. Prakt. Chem., [2], 36, 16(1897); O. Baine, G. F. Adamson, J. W. Barton, J. L. Fitch, D. R. Swayampati, H. Jeskey, J. Org. Chem., 19, 510 (1954).

4) C. Dufour, M. Graizon, A. Buzas, Bull. Soc. Chim. Fr., $1951,104$.

5) H. Hübner, O. Brenken, Ber., 6, 170(1873); 平尾一 郎, 小抢暜婎, 未蒔武利, 有合化, 26, 439(1968),

6) J. L. Hecht, Amer. Chem. J., 12, 502(1890); C. Mentzer, P. Meunier, Compt. Rend., 225, 1329 (1947).

7) 践居三吉, 中目 秷, 日特, 8965(1958).

8) Th. Zincke, $A n_{*}, 261,208(1891)$; P. S. Ugryunmov, Zhur. Obshch. Khim., 19, $1167(1949)$.

9) G. Wittig, Ber., 57, 88(1924); A. Bhati, J. Chem. Soc., 1963,720 .

10) R. Stollé, E. Knebel, Ber., 54, 1213(1921).

11) S. B. Richter, U.S.P., $3,013,055(1961)$.

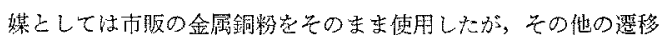

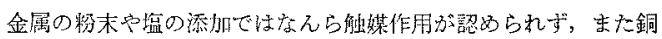

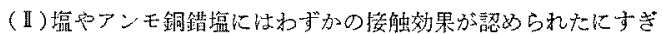
なかった。得られたヒドロキシ安息香酸趋剩の硫酸シメチルで メチル化したの方ガスクロマトグラフィーに上り分析を行なう とカカルボキシル基は医々んどが水酸基に対しパラ位置に入って おりサリテル酸の生成量は少ないことがかかった。したがっ て，得られたヒドロキシ安息橗酸をエタノール水溶㴕から一度再 結晶するとほとんど絊粋な 4-ヒドロキシ安息香酸が得られる。 最初に銅螌媒上四㫫化炭素の全量を系内に入机て区応を行なう と，反応開始後 2 時闒くらいふら反応率曲線がいらじるしく低勾 配になり，銅触媒の活性方゙弱まってくるのがわかる。したがっ

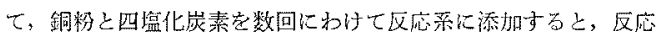

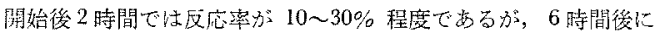
は 50〜60\%となり全量を一度に加えた場合上りもかなり反応䓋 が高くなる(四 1 )。

水凌化ナトリウム溶液の摆度の影響は 40 50\% 溶液上 $30 \%$ 溶液ではかなり反店率に差(30〜40\%)が認められる。しかし $50 \%$

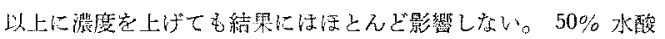

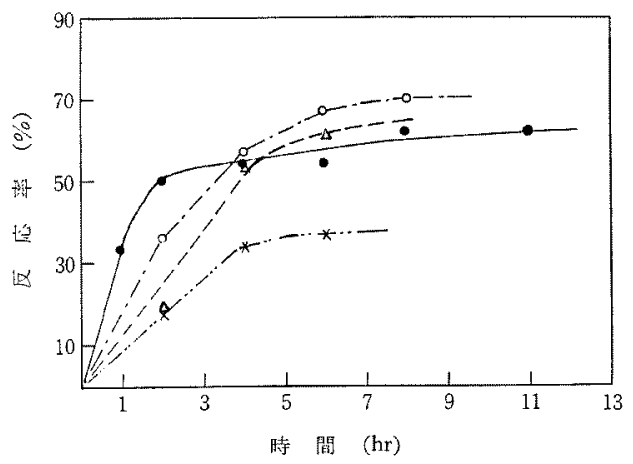

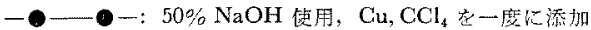

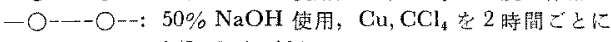

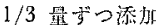

$-\triangle--\triangle-: 40 \% \mathrm{NaOH}$ 佑网, 闹上

$-X-X-X: 30 \% \mathrm{NaOH}$ 使用, 同上

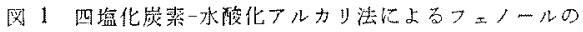
カルホキシル化反応の反応督曲線 (㯰度 $80 \sim 85^{\circ} \mathrm{C}$ ) 
化ナトリウム水淮液についてフェノールー水酸化ナトリウムの量

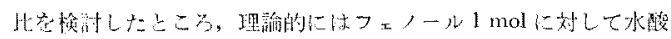

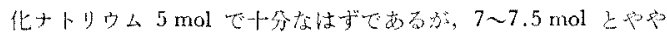

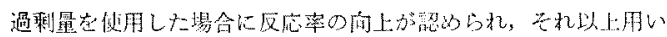

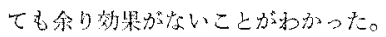

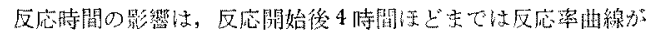

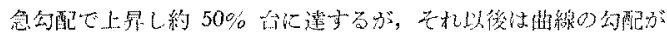

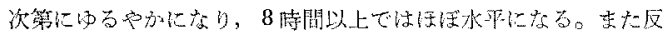

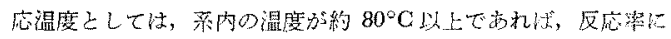

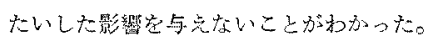

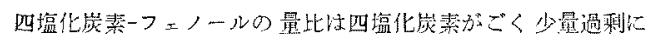
存在するがり反応率にはほ上んど影響を与えない。

フェノールについて得られた以上の知見に基づいて2-就よ゙ 4-クロルフェノール, 2,4-, 2,5- 怙よび 2,6-シタロルフェノー ル，2,4,5-トリクロルフェノール，4-クロルー3-メチルフェ - ル, 6-クロル-2-メチルフェノール, 4-クロル-3,5-ジメチルフェ イールの9程のタロルフェノール類について直接力ルボキシル化

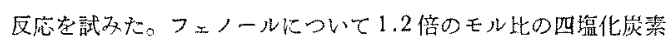
上 7.5 倍のモル比の水酸化ナトリウム些湛度 $40 \%$ の水溶液とし

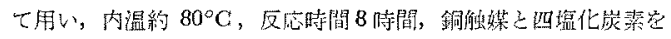

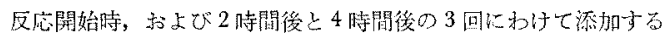
方法によって得られた絬果を表りに哥した。

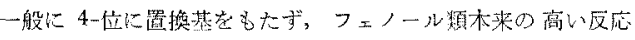
性がや抑兑られた 2-タロルフェイールや2,5-ジタロルフェ， 一ルの場合には良好な結果紧得られるが，2,6-シタロルフニノー

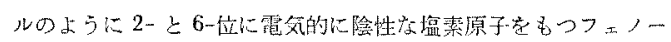
ル類ではカルボン酸の取萃がいもじるしく低いことがわかる2，

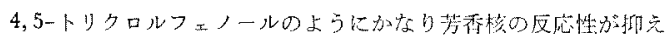

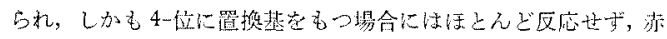
外吸收スパクトル薄層クロマトダラフィーによってヒドロキシ 安息香酸の生成が確認されるにす巳゙いが，オートクレーブを用

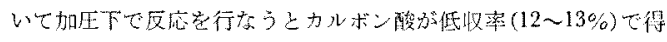
られる。タロルフェノールら反性がや和高的られたタロルメ

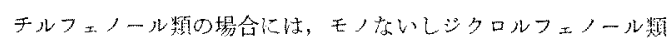

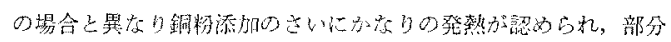

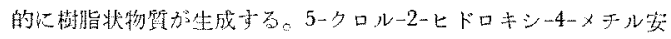
息香酸ならびに3ータロルー6ーヒドロキシー2,4ージメチル息香酸 ほそれぞれ 6-クコル-2,7-シメチルクロモンの水酸化ナトりウム

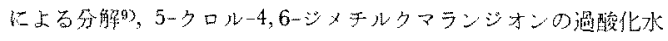

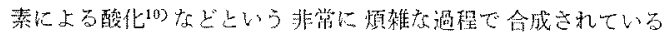

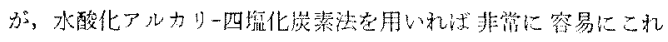
らを合成することができる。

一般反民応性はクロルメチルフェノール，クロルフェノール， ジクロンェノール, トリタロルつェノ一ルの順低下し，4-低 のあいたクロルフェノールの片加 4-位に置換基志もつタロルフ

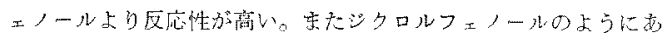

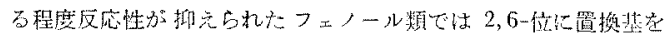

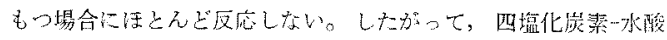

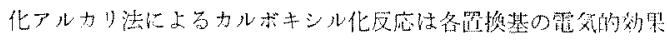

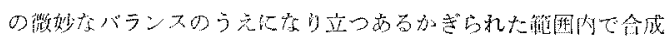
上の意转をっていることがわかる。

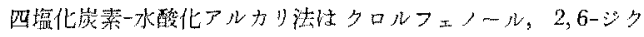

ロルフェノール粈外のシタロルフェノールおよびクロルメチル

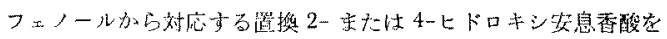

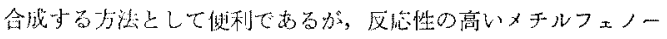

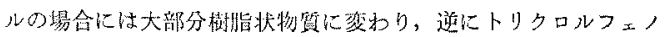

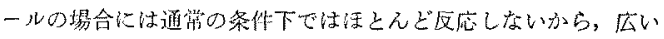
通用性定もつ一般的な合成法已は必它ずしもい党ない。2,4,6-卜 リクロルフェノールや2,6-ジロルー4-メホルフェノールのよう

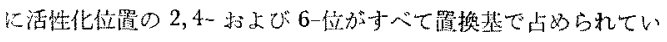

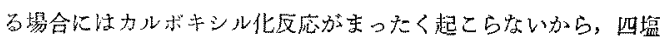
化炭素一水酸化アルカリ法も Kolbe-Schmidt 法の場合と同㥞に 3ーヒドロキシ安息香酸誘慗体の合成には使用することができな wo

\section{3 実 験 の 部}

\section{1 試 料}

2-および4-クロルフェノール，2,4-，2,5-括よび 2,6-ジ ロルフェノール，2,4,5-トリクロルフ ニール，4-クロル-3-メ チルおよぴ 2-クロルー6-メチルフェノール，4-クロルー3,5-ジメ

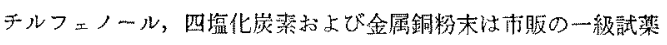
を精製せずに使用した。

区度生成物の確愁は元素分析, 赤外吸収スペクトル怙上び別途 に合成した䌘淮陚料との比較によって行なった。

\section{2 四吘化宸素とクロルフェノールの反心}

2,5-ジロルフェノールが 2,5-ジクロルー4ーヒドロキシ安息 香酸の合成と,4-クロルー3,5-ジメチルフェノールから5-クロルー 2-ヒドロキシー4,6-ジメル安息香酸の合成ををれぞれつ

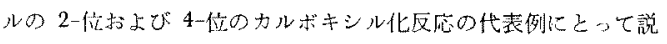
明する。武居と中鼠怯特殊な条件下゙て 2,5-シクロルフェノール の Kolbe-Schmidt 反忘を行ない2,5-ジクロルー4ーヒドロキシ安 息香酸虹合成しているつが，このさいにはかなりの量の3,6-ジタ ロルー2ーヒドロキシ安息香酸が副生し，ての分㓢操作が頇雑であ るから本法による合成の力が便利でする。

3.2 .1 2,5-ジクロル-4-ヒドロキシ安息香酸：還流冷却管，㵜

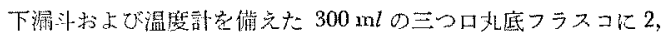
5-シクロルフェーール $16 \mathrm{~g}(0.10 \mathrm{~mol})$ と金属銅粉 $0.1 \mathrm{~g}$ をとり,

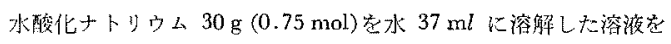

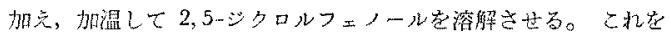

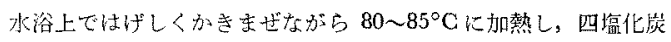

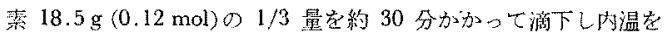
約 $80^{\circ} \mathrm{C}$ になる上らにたもつ。反応液は次第に銅（II)イオンのた

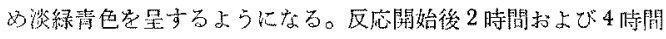
たったときにさらに金腹銅粉を各 $0.1 \mathrm{~g}$ ずつ反応系内に添加し，

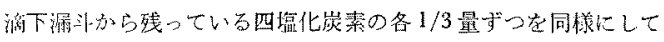

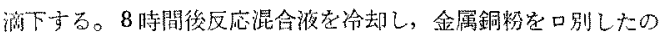

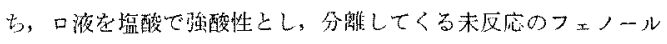
扔よび尘成したヒドロキシ怒息酸家エーテルで抽出する。さら

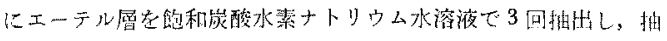

*4 2,6*ジロルフェノールのカルボキシル化に上って生成 寸る3,5-ジクロルー4ーヒトロキシ安息香酸はpーヒドロキ

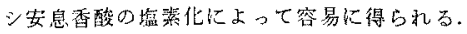

C. Y. Hopkins, M. J. Ghisholm, Can. J. Research, 24 B, 208(1946) 


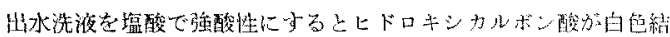
晶として沈殿してくる。これを吸引口勋し，口波りエーテル拥は

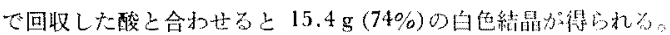

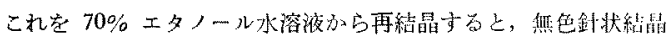
$11.0 \mathrm{~g}(53 \%)$ として得られる。 $\mathrm{mp} 219 \sim 220^{\circ} \mathrm{C}$ (效献值 $258^{\circ} \mathrm{C}$ ) ${ }^{*}$ 。

ごく少量の 3,6-ジクロルー2ーヒドロキシ安息香酸 $(\mathrm{mp} 188$ 190 $\left.{ }^{\circ} \mathrm{C}\right)$ 1)が相伴って生成しているが，こ礼は再結晶仙上って容易に

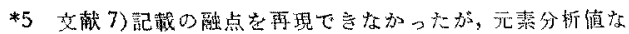

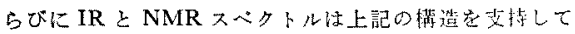
いる.

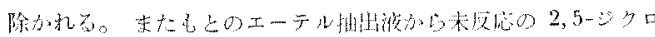

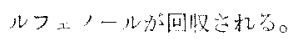

3.2 .2 3-クロル 6 -ヒドロキシ-2, 4-ジメチル安息香酸：4-タ

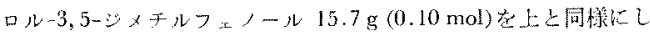

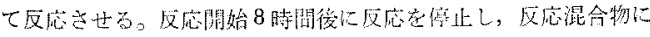

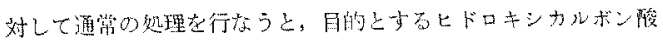

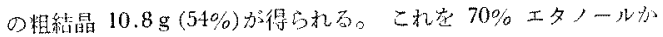

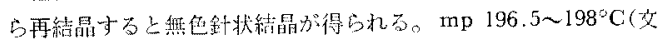
献淔 ${ }^{10)} \mathrm{mp} 193^{\circ} \mathrm{C}$ ) 。

\section{新しいカルボジイミドの 合成 法}

(炤租46年8月9日受理)

$$
\text { 古 元 貞 好*1 }
$$

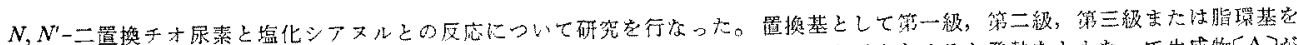

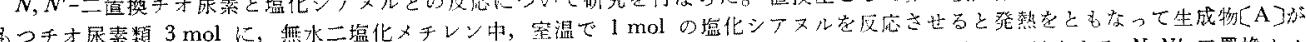

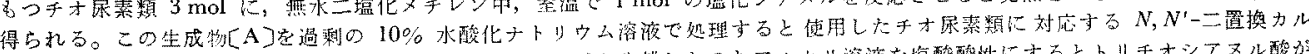

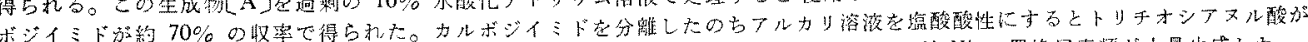

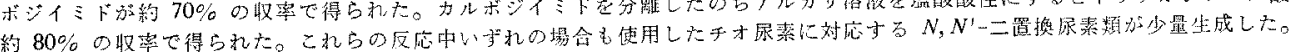

\section{1 緒言}

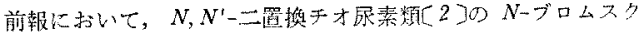

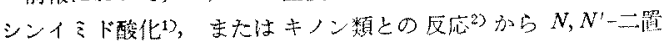

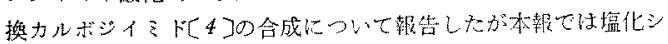
アヌル[1]上チ才承素類加らの力法以ついて調バた。最近Pollak

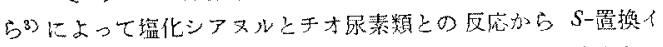
ソチ才层素類の生成するこ上が報告されているが关の取萃ききわ

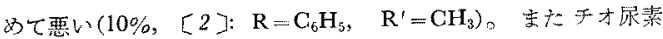
(〔2】: $\left.\mathrm{R}=\mathrm{R}^{\prime}=\mathrm{H}\right)$ と塩化シアヌルの反忘心口得られるイソキ才 ウロニウム塩を水酸化ナトりウム溶液で分解してトり早オシアス

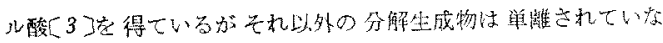

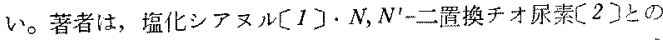

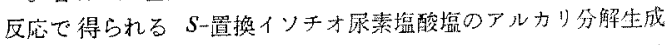

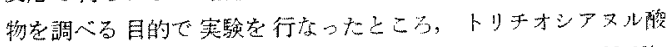

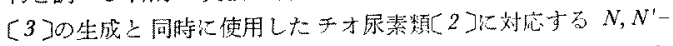

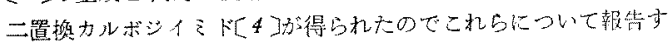
る。

\section{2 結果と考察}

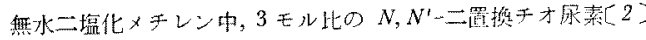

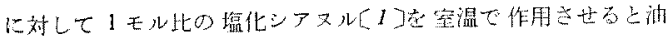

*1 Sadayoshi FURUMoro 挑式会社大限合成看機化学研管 所, 西宫市上田東町

1) 古汇真好, 日化, $91,359(1970)$

2) 古元真好, 日化, 92, 357 (1971)

3) A. Pollak, B. Stanovnik, M. Tišler, Can. J. Chem., $44,829(1966)$.

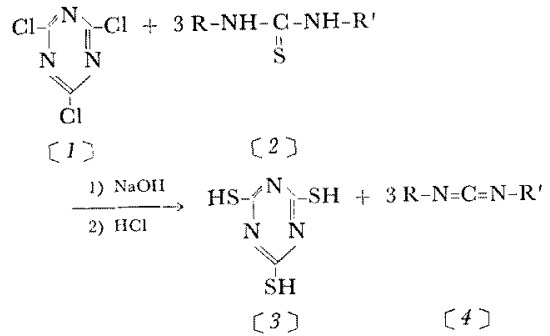

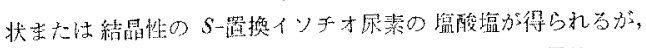

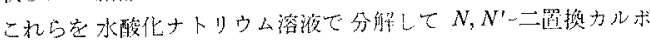

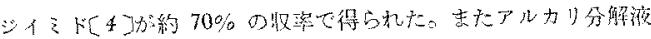

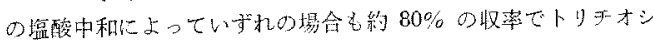

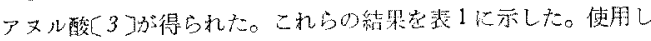

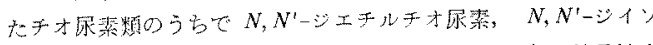

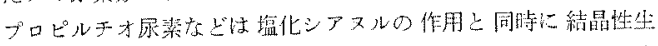

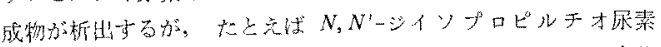

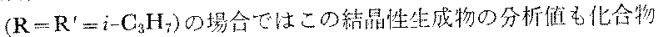

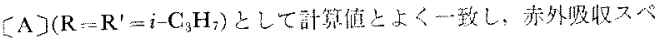

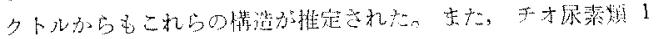

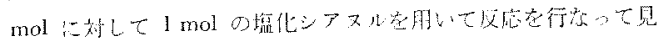

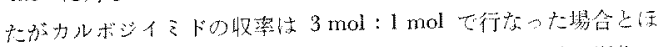

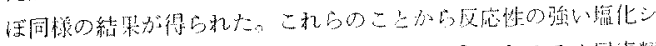

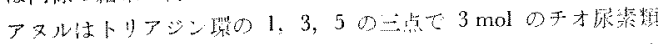

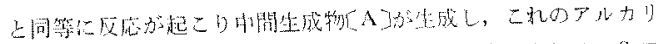

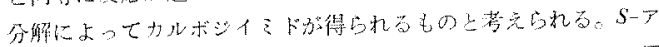

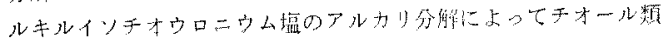

